\title{
CIRCLE DRIVE
}

by

Matthew Naples

\author{
A thesis \\ submitted in partial fulfillment \\ of the requirements for the degree of \\ Master of Fine Arts in Creative Writing \\ Boise State University
}

May 2018 
(C) 2018

Matthew Naples

ALL RIGHTS RESERVED 
BOISE STATE UNIVERSITY GRADUATE COLLEGE

\title{
DEFENSE COMMITTEE AND FINAL READING APPROVALS
}

\author{
of the thesis submitted by
}

\author{
Matthew Naples
}

Thesis Title: Circle Drive

Date of Final Oral Examination: $\quad 27$ February 2018

The following individuals read and discussed the thesis submitted by student Matthew Naples, and they evaluated his presentation and response to questions during the final oral examination. They found that the student passed the final oral examination.

Martin Corless-Smith, Ph.D. Chair, Supervisory Committee

Janet Holmes, M.F.A. Member, Supervisory Committee

Kerri Webster, M.F.A. Member, Supervisory Committee

The final reading approval of the thesis was granted by Martin Corless-Smith, Ph.D., Chair of the Supervisory Committee. The thesis was approved by the Graduate College. 


\begin{abstract}
The massively multiplayer online role playing game, World of Warcraft follows many leveling systems that spoon-feeds its players a steady and carefully calculated sense of progression, control, and power. This is part of what makes the game so appealing, as well as the intricate character creation and vast community-based elements. Millions of players share this world of Warcraft, as if it were its own real world (and in a way it is), and they do so with characters they've created and customized. What furthers this connection between player and character, and player and player, is how their characters move and act in accordance to the input provided by the players on their keyboard and mouse.
\end{abstract}

"Circle Drive" examines the illusion of World of Warcraft's progression, success, and control of characters through roles, by pairing it alongside a turbulent family dynamic. It spirals through the "story" of a family of three (mother, father, and son) where the teenage son becomes dependent on World of Warcraft, eventually teaches his Mother how to play, then the Mother becomes addicted as well, finds a boyfriend through the game, has an affair, splits from her husband, moves away, and the house is eventually foreclosed and left to rot.

The pastoral lyric is used in section five titled "Foreclosure" as a way of encapsulating the nostalgia of a speaker coming back to their childhood home covered in weeds. The spiral orientation of moving, but being stuck, as if a person is spinning round in circles is 
representative of a player addicted to WoW. They are doing something, in that they are playing the game, and they think they are making progress and success, but its only successful to the people in the game. Once the game is taken away, there's just a person who sat for hours in a chair. Repetition of form and words highlight that obsessive insanity as well.

Video games create an illusion of linearity, with their leveling system, and many stories follow that system as well; however, "Circle Drive" shies away from that impulse and instead relies on the lyric and improperly ordered sequences to emphasize placelessness. 


\title{
TABLE OF CONTENTS
}

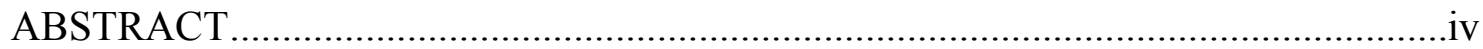

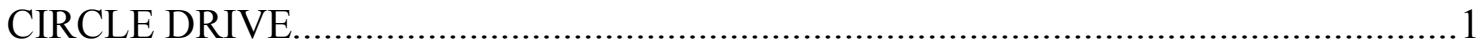



Circle Drive 


\section{Content:}

\section{Cast}

- Deuz [level 1] [Orc Warrior] -

\section{Family: A Role Playing Game}

1. Shadow Business - 8

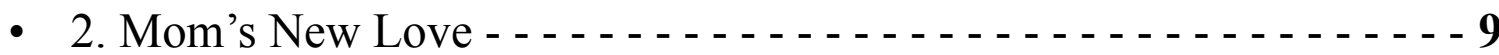

3. Promise -

4. You - 11

- 5. Arms - 12

- 6. A Snake Can Eat Its Tail - _ _ _ _ _ 13

o Loading - . 14

- Deuz [level 40] [Orc Warrior] - - 15

o Battle Ground - . . . 16

o Battle Ground - . . . . 17

o Deuz [level 70] [Orc Warrior] - . . . - 18

- 7. Timber Could Have Drowned - - _ - _ - 19

- 8. Scapegoat - 


\section{Wrath of the Lich King}

-My son, - - $-\ldots$

- ALT F4 -

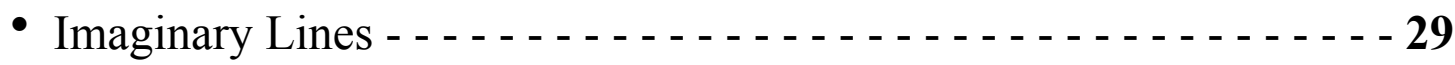

- Try - - - $-1, \ldots$

\section{Player \& Deuz}

- QUEST ONE - $\ldots \ldots$

- QUEST TWO - $\ldots$

- QUEST THREE - $\ldots$

- Deuz Said To Me $\ldots \ldots \ldots \ldots$

\section{The Circuit Compulsion}

- Wavelengthener - $\ldots \ldots \ldots \ldots$

- Addiction - - . -

- The Deer - _ $\ldots \ldots$

\section{Foreclosure}

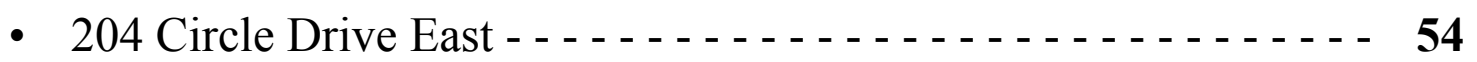

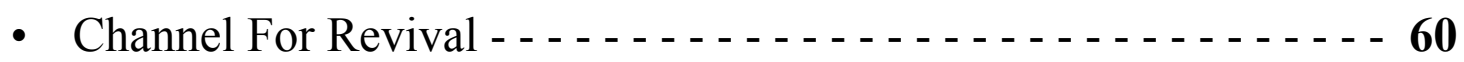

- As A Thing - . $\ldots \ldots$

- The Computer Tower - - - - - - - - - - - - - 68

- Still Electric - 


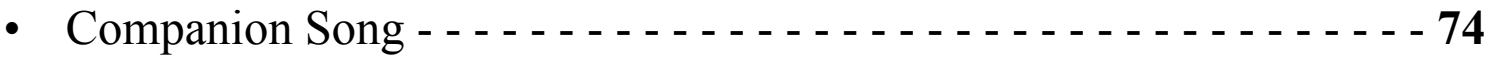

- Parallax - $\ldots \ldots \ldots \ldots$

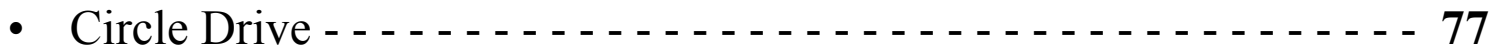

Notes 


\section{Cast:}

World of Warcraft (WoW): A Massively Multiplayer Online Role Playing Game (MMORPG) that Player played from 2004 to 2010 and has obsessed over since.

Player: White Male Gamer. Sometimes 15. Sometimes 20. Sometimes 27

Deuz: Large, green skinned Orc Warrior, created by Player in 2004.

Arthas Menethil: Crown Prince of Lordaeron and Knight of the Silver Hand, was the son of King Terenas Menethil II and heir to the Kingdom of Lordaeron. Arthas murdered his Father then made his way to the Frozen Throne of Icecrown and to merged with:

The Lich King: Master and Lord of the Scourge, which he rules telepathically from the Frozen Throne atop Icecrown Glacier.

Luke: Family dog. German Shepard / lab mix.

Timber: Family cat. small. calico.

Mother: Nurse. Played WoW.

Father: Cop. Did not play WoW.

Bruce: Police Chief. Father's boss.

Blood Elf Paladin: Mother's boyfriend of seven years. 


\section{Deuz [level 1] [Orc Warrior]}

His hands are green and large and full of hope.

When I envision them at night, they are two eagles

Cartwheeling to better land. 


\section{I.}

Family: A Role Playing Game 


\section{Shadow Business}

- July 2005

$15 \&$ I need Horn of the Frostwolf Howler

sneak my hand into dad's top drawer

glock on the right, small cardboard

box next to the underwear in between

the plastic number's scaled armor

$\&$ it's awesome

typing what's on the screen: currency

for currency. hours later: in-game mail:

"800 gold

- ty"

My mount is now an epic.

We can go $100 \%$ ground speed. 


\section{Mom's New Love}

- April 2009

She met him in Stranglethorn Vale while fighting tigers

She, a Blood Elf Hunter

He, a Blood Elf Paladin

He was different from the others

We'd talk for hours

He told me how his sister would poke him with a fork

How his father ran him under cold water before his beatings

How he hates it when it rains because that's when people steal 


\section{Promise}

- December 2009

I promise you Mom I promise

In the Burger King parking lot

But you won't budge

But I'm your son

Promise me son, promise

When I tell dad tomorrow

He promises also 


\section{You}

- December 2009

Yes, may I speak with Nurse Naples

Yes, this is her husband

Thank you.

$Y O U$

I don't like that word

The way he stretched you out in it

Or how I helped him pack your stuff

And didn't cry when we hugged goodbye 


\title{
5. Arms
}

- December 2009

\author{
Listen son, \\ - I'll give my guns to Bruce \\ - I don't need a shrink \\ - We'refine
}

\section{The Warrior Class}

Warriors are melee fighters highly trained in the art of weaponry. Melee combat is the Warrior's strongest skill. They are strong and quick on the battlefield. Depending on their specialization (Arms, Fury, or Protection) a Warrior can often deal very high damage or be tough to kill. Warrior abilities depend on rage generation. Rage for Arms and Fury Warriors generates through auto-attacks, while rage for Protection Warriors generates primarily through taking damage.

\section{Arms Specialization}

Strengths:

- Very powerful single-target priority damage and burst

- Frequently available cooldowns that have a large impact on output

- Strong cooldown based Area of Effect burst

Weaknesses:

- Very limited by cooldowns and Tactician resets which can be unpredictable

- Sustained Area of Effect damage is average

- Can frequently become resource starved limiting ability uses 


\section{A Snake Can Eat Its Tail}

- January 2006

She called me on her way back from work

Asked me what I was doing

As if she didn't already know

How about you teach your Mother how to play? 


\section{Loading}

The mmmouse

mustt ressst

overrr ttthe pauldren

((his left))

((my right))

betwwweenn

the spike

arrchhing towward

Azeroth's twwwoo moons:

The Blue Child / The Embrace

as the otherrrrr

spike aimmmsss

squarely at the heartttt

of us 


\section{Deuz [level 40] [Orc Warrior]}

His hands are covered in platemail gauntlets.

When I envision them at night, they are a fortress

On a cliffside terrace. 


\section{Battle Ground}

Caught in the coal's canopy with dust,

The Mine in Arathi Basin sits to the right

Of the Lumber Mill, on a hill, which hulks

To the left of the centralized Farms. It's here

Where I whisk past my Avatar's adrenaline

As pixels inside raised auxiliary wings! — a buzzard

Strapped atop my Howler's wolfen cavalry. To fell

Counter, and tack together our green and red bars

To hit points — both of which clears movement-

Depends on how well this axe plummets. Order

Helmets each compression as attempts to stun

I'm oblivious. My fingers click my sticker off. 


\title{
Battle Ground
}

\author{
Always with that same cover \\ The Mine in Arathi Basin sits to the right \\ Of the Lumber Mill, on a hill, which hulks \\ To the left of the centralized Farms. That's right
}

My Avatar smashes ya peanut slide

As pixels inside raised auxiliary wings-

You crackle spawn as my Wolf's slobber

Slashes all these baby mouthed fiends!! HAHA HIT!!!

Boing —! Inner move-?!

Depends, son. On how well this axe plummets. Order

Helmets the compressions as attempts to stun

I'm different. Just like everybody else. 


\section{Deuz [level 70] [Orc Warrior]}

His hands were green and large and fully grown.

When I saw them again last night, they were two chariots

Encircling themselves in sand. 


\section{Timber Could Have Drowned}

I'd like to have more discipline in my life like the army men I played with next to the above ground pool in my old house's backyard. I wonder what's inside there now? After you kicked mom out the mosquitos crept in. Then the frogs hopped along and laid their eggs. Soon afterwards tadpoles swam around lost in a green sludge that was once a place mom floated on an inflatable raft to read in sunshine.

I bet right now it's still smashed in and I remember that time when I came back from delivering pizzas and brought back a hoagie then no longer wanted it and so I tried to throw it deep into the woods from the deck's edge but didn't make it like I always did with the beer bottles I pounced down my throat when the two of you were still at each other and decided to go shopping together leaving me in the house to dance around and eat baloney in the kitchen and not worry.

It landed in the pool. So when I came home the next night you toldme you heard a splash from outside but didn't do anything because the TV was on but thirty or so minutes later you heard our cat mewling at the door scared out of her mind and completely drenched in a green slush and I couldn't help but think that she must have jumped into the pool after my hoagie. 


\section{Scapegoat}

It's the score a run through

Duskwood at 15 It's chasing

How I want to change

The name of my Dwarf Paladin

It's I didn't realize

Till level 20 It's the foreign world

The sightseers The litter box

The Game Master who didn't honor my petition

Before I go is there anything else I can help you with?

You didn't It's Lady Gaga My part-time job

It's letters Alphabets The Lich King

The wick from candles I'm holding

Onto 204 Circle Drive East

Cut grass Open wind

It's Timber being kicked out the door

During Monday Night Football It's the birds It's an XL

Dawkins Jersey flapping down the hallway

The wall of shame It's the 21 photos

Of me We can look It's my hand

Over my chest It's the remotes

The computer screens The underwater breath

The unmarked car in the driveway It's the fireflies 
It's techno It's circles Olde English 40s

It's Super Bowl 39 It's cheesesteaks

I'm holding onto It's cheese

It's manhunt through a meadow

Muskets and plastic grenades

Invisible blood A human tank

Riddles It's crooked teeth The Delaware

It's tick bites The branches behind the fence

It's my hunger for attention Obsessive

The top of the drawer Plastic bags The shower knob

It's dancing It's in the water It's in the meat

It's in my terror It's the winter Cartoon Network

The SSV Dodge Durango It's nested in our driveway 


\section{Wrath Of}

The Lich

King

My son,

The day you were born

The very forests of Lorderon

Whispered the name

Arthas 
My child

When you came through the door

I watched with pride

And brought down a mountain

As you grew into a weapon

Pounding on the table

Of righteousness 
Remember

When I smashed my remote

Our line has always ruled

And placed it next to your smashed remote

With wisdom

And wrote on a sheet of paper: "Let's see how far this will take us."

and strength 
When I'm lined up

And I know

For the foul shot

You will show restraint

And don't know

When exercising

How to tune out

your great power 
When we win that game

But the truest victory

You run onto the court

My son

And with one arm slam the ball up to the rafters in celebration

Is stirring the hearts

And I'm in complete awe

Of your people 
Keep your eyes locked

I tell you this

Your elbow up!

For when my days

Your chin straight!

Have come to an end

Don't choke!

You

Follow through!

Shall be king 


\section{ALT F4}

this crane I keep in a box

lives where he does because he is small

always searching for his brush

he loves to paint the shores he does 


\section{Imaginary Lines}

I wanted to dig away I wanted champions To wall To haul upward To mix

Confetti and remembering Belief between next And please I wanted diagrams

Insides with Live intent Smiles eyes hands I wanted graphs Paws I wanted to

Cross the water and know that I crossed it I wanted a terrible story to share itself 


\section{Try}

He stops

watching

because my bike

isn't going

down the hill

outside

our driveway,

but he solves

my crying

by throwing me

through the front door,

the back

of my head

shifting

the stove

in addition

to the trident

now in

my hands. 
Captured! Hill rocks! Abracadabra!

Handprints on the run from punish

Befuddled into the utmost uh-oh

Comedown and insoluble bubbles

Tautened by the brackish waterlogged

Basement and sump-pump that must

Have wanted to drown itself in loudness

Loudness that wanted to drown itself now 


\author{
He stops \\ watching \\ because \\ my trident \\ isn't going \\ through his chest, \\ but I solve \\ this trial \\ by picking \\ hurry
}


Configurement. Door spawn. Great One!

Hammer plan an infernal wander I will

Reflexively. Keep the Handle important!

To me. Glass Index / Middle System cordage

Sequences that dig. I want it there. To hear

Experience. To See. Myself. Thing. 


\section{Halftime}

-I don't know

when

was the

last time

you and I

designated

space in

our living

room to

pretend play

a football game?

Our bodies talk

playing softly

as rug scrapes

with a plush

toy plastic

helmet and

at what point

did we

determine

we were too

tough for that game? 


\section{Player \& Deuz}




\title{
QUEST ONE
}

\author{
- A Computer Powers On
}

Sing in me, WoW, and through me tell the story

of that Orc and Player, both skilled in pretending,

the two wanderers, harried for years on end

after plundering the frosted citadel of Northrend

to dismantle the reign of The Lich King: Arthas.

They saw The Barrens

and learned the minds of many distant players, they weathered many bitter nights and days

in their hearts through sand dunes and jungles, through snow fields and mountains. They fought to saveto bring themselves home. 


\title{
QUEST TWO
}

\author{
- A Hero Awakens
}

When primal dawn spread across Kalimindor's sky

Player's fingers clicked on the light, and Deuz, level 1,

Orc Warrior, was spawned. He drew on his tunic

with sharpened axe, pulled up his patched trousers, strapped

up his leather boots, and together, Player \& Deuz found their first quest

as the slow scroll of shorthand unrolled the message:

Finally, you are of age, Deuz, of age to battle in the name

of the Horde. To conquer for the glory of the Warchief.

Yes...

$<$ Kaltunk looks you over. $>$

You will do nicely.

No doubt you wish to find a great dragon or demon and strangle it with your bare hands, but perhaps it would be wise to start on something less... dangerous.

$<$ Kaltunk laughs. $>$

Report to Gornek, he should be able to assign a task better suited to a young warrior. You will find Gornek in the Den, to the west. 


\section{QUEST THREE}

- Cactus Apple Surprise

It sure gets hot out here in the Valley of Trials.

$<$ Gornek wipes his brow.>

If only I had some cactus apples, I could make my famous cactus apple surprise!

Nothing cools you off faster than a piece of that delicious treat.

I'll tell you what, Deuz, if you bring me 10 cactus apples, I'll make you

a few portions of cactus apple surprise to take with you on your adventures.

If you're interested, you can find cactus apples growing near the cactus plants around here.

The cacti bloomed in sporadic patterns around the red

cracks atop the canyon's floor. With a scan of the mouse

point, in the form of a gray gauntlet, Player was able

to locate the appropriate foliage, for the gauntlet turned

into a bronze gear when hovered over the proper harvest.

Thankfully, Deuz was quick to dispatch of the scorpion

and boar that threatened their cactus apple surprise. 
SHUT THE FUCK UP!

$<$ dinnerware smashes.> 
At evening came the Lich King with his skeletal

Scourge, undead cavalry, and Sindragosa-

Her ice-breath and bone-wings spread over snow

Capped mountains beyond the Citadel's frozen lawn.

Your father and I are concerned. He's threatening

to throw the computer into the pool. 


\section{Deuz Said To Me}

I am not yours!

Right before he leapt

From the screen, having hauled

My watch for too long. The change

In my heart since then has worried me

Despite my computer's unbroken hum.

But to Deuz, it seemed his body

Was more than just those components,

My gaze and trust, for he saw the ice

And wanted to break. Saw the cardinal

Through the window stand still

Like a blood drop in snow. 

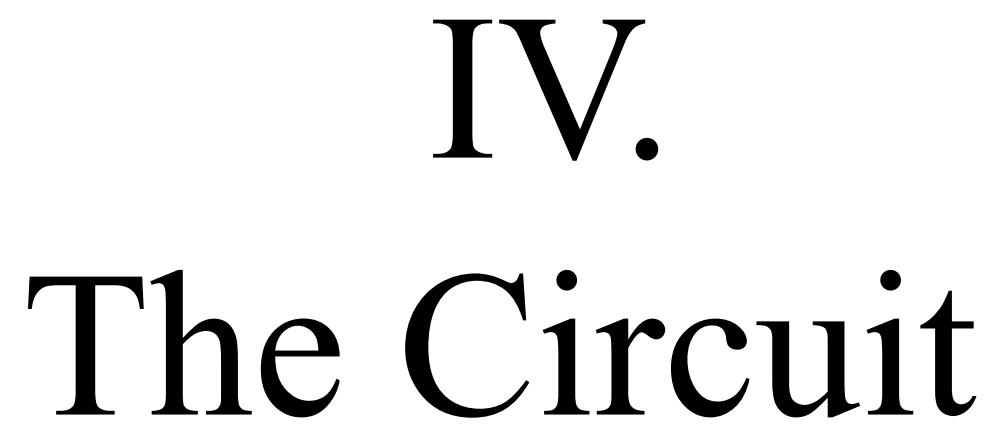

Compulsion

The moth don't care when he sees the flame

He might get burned, but he's in the game

The moth don't care if the flame is real

The moth and flame have a sweetheart deal

-- Aimee Mann

But if I would show the good that came of it

I must talk about things other than the good.

How I entered there I cannot truly say,

I had become so sleepy at the moment

-- Dante Alighieri 


\section{Wavelengthener}

When careful is kept inside a shell,

Swept quietly, as signals Consolidate on top of the quiet

Beams, an Elemental crawls forward

Full of water, full of foam,

An island to its hydrolatry.

But what files its fortress?

When careful is kept inside a shell

Swept silently, as signals

Wield asymmetrical patterns

Beams! Elementals walk forward

Full of folds, hydration leaps

Absorbed. But what slides

Into the microwave for more? 
I'm tired of myself too. Inside

A shell, signaling

Sampled patterns, boarded hoaxes

Over and old. Water Elementals

Swarm forward, full of filthy

Inert oceans. But what guides

Me into that pull? 


\section{Addiction}

despite the violence I love

remembering momentum wings

the swing set and the boy you

singed, lost in the home's crest

you fall back away from because

you call back impassionate dawns

when you light your shell it runs

your palmtop and login worship

darkens the hill you then cross 
each segment a little dig treason to your weight its venom, brawn, tired by it, announcing last night if I kill it I can't worry but I'm afraid of the basement because that's depth, mold made ponds, shaken circuits where I can't light I'll cement three pigs who enter the heart grunts on hooves four to a pair, pairs to the up decisions creating storage two times their floor sprawls so long as I make it confusing stretch then cancel wings I can master this cloud only two percent of the sun hits this jungle's floor 
online in our order

where we can fly

enclosed in tunes, in glass

breath, reminding us

our world is always ours:

a mirror, amazement

mirage-less, a non-heat

wielding two-handed axes,

rectangular heads, we have them

calculate, crackling twenty

forty, sixty, eighty, the numbers

are an insurance, a bulwark

to us, the receptive all fill

nocturnal tilt and realm dance

dream mechanism of twelve million

avatars in one magical stick

a cannon draped in linen 
at night the shades spin

thrown down undercover

the shades spin, made anguish

from out the glass, grumble

I'm enough, so, they say I am

although I'm not holy to me

or holding virtuous lightness

exposing all of my own weapons

at night exfoliating my whole head 


\author{
I'm disgusted by sleep \\ iron, domed mattresses \\ wall-to-wall carpets \\ feather with no flight \\ a plank, tethered sheets \\ a song in a box \\ light water on roofs \\ downtown two robins \\ scratch the backs of wings \\ dawn despite me
}


I'm praying in the sand hills

where coal steps the tracks

are my footprints terrible

barons of instruction

submerged fire, a peninsula

are my terrors a vehicle

underwater clocks, watchdogs

frozen music, what can lift

me and play, to take me home? 
In our house, all the plastic is turned and the mirrors are covered. We sit like wood in the fresh window light and keep our eyes up. Sometimes the words we hold spin and make us smile. On the deck toward the pool the honeysuckle vines smell, the honeysuckles with their silent weeds think about us, we know this. We rock back and forth to calm ourselves, and kiss our fingers when the doorbell rings and don't answer in the winter when the fur grows stronger on the backs of the deer outside as ice thickens the pool cover we sleep on in the same position every night to see our breath together and remember this opened is the spirit alive. 


\section{The Deer}

I didn't know our hearts

would open like our breath

in the cold on that hill

where three grown deer

walked softly past, as if this

wasn't already owned, made

huddled inside us. Maybe

that was our one imagination-

what we wanted to leave

what we kept dreamt

where no one intended

the results fluttering inside of our mouths. 


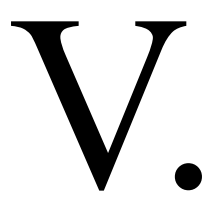

Foreclosure 


\section{Circle Drive East}

- June 2016

It's warm in there

Plywood squares

Dust and pans

Garden and shed

That tree was planted

A shadow capsule

Gravel windows

Grass thoughts

Deer jaws 
There used to be a swing set a small above ground pool

There used to be a wren's nest a mouth small and narrow There used to be a short tin roof a pool flowering with grubs Their music strips the basement a small crown above the rest 
- March 2010

Dumbbells

Wet cement blocks

When it rains enough

The sump-pump chirps

Enlarging the night

We use bleach

The spring peepers

Call an infestation

Things are going to be tough

We let them circle 
- July 2009

Mowing the front yard then going

Where the little hill slopes the night

I crawl armyman into your voice

A channel through the phone's edge

Onto the deck next to the pool's quiet

Snapshot of the moon in water

The moon!

Look Mom! The moon has swallowed me!

A little pearl bulb you fan up 


\section{- basement}

The network of the spider is a passion

in its chamber the channel takes the lightning

that comes above to worry. The webbed manacled feathers

spread their scissors-

one walks by another. 
- backyard

Three people in fresh snow

Getting rid of themselves

Slowly, each with different motions

Three people in wet coats move focus

Back to the path along the woods

In their hands cutting cold

Three people in slowed snow

Hold on to each other

Next to the edge along the woods

The path, the snow licked bones

Feels the snow lick their coats

A breath's web above the rest 


\section{Channel For Revival}

After wind in the form of an Andalusian horse rips me loose from the jowls of a crocolisk tethered to the channels of The Southfury River,

I will come back to you, WoW, fully coaxed, having ran too seriously away from us. My arms will stretch into new luggage, a new watch will form, as we walk

our environment closely, our hands open. Even as you strangle me pixilation. A person changes a sequence diagrams the lines rip chance- lifts

to give, closeness drawn, LAN lighting palaces where clouds passage armor quickly through a headset above a hat above an adolescent's skull

where two buoyant arms fix onward, hearthed home. Remember, fingers, must we be that head above a grey hat above what small skull

experiences the lawn, grass cuts in gloves and 200 pounds of loud words. Hear your answers, a little striking, to bring you war and more honor, viruses, gold. Start slow, be persistent, fingers, and your levels will increase the amenities at night, modifying the vibrations 
from jingled house keys. The lie is I grow-

palisades - the way they keep form against

mindlessness, as the mind is felt, mind as fish

opaque clouds, smoke-swirl in crystalized balls-

you let me drone. I'm droning now, losing hours

until the horse carries me back in its saddle of leaves

to rest, where I don't care to worry. I can stand still now

like clockwork on our abandoned lawn. My intervals click

and entomb the world. But to have lived in you as I did, with love,

despite our incompatibility, should guarantee my passage

will not take long. Make it happen, and whatever you need,

I'll be going, you know that. Even if you stop me. 


\section{- driveway}

It stands on target and the tree did that

To the trowel and the boots aren't there

And it spills - I keep taking pictures

Of deer eating weeds in the driveway. 


\title{
As A Thing
}

Because When

it shines

Image in front speaks

Stamped in metal

Screen said

You are not

Real enough

You don't

Fill this room

\author{
Well I went \\ And became real \\ Real enough \\ To be saved
}




\author{
Screen said You \\ are not Fearless \\ enough You \\ don't
}

Hear yourself

Well I went

And plugged in

Myself, enough

To overflow

Screen said

You are

Too clever

Filled with

Imagination and doubt

Well I went

And became a stone

Hardened away

From everything 
Screen said

You are too dull

And don't move

Anybody

So I went

And became Statue!

Standing firm

And awesome

Screen said

You're just a chisel

Sculpting every thing

And every one

You see

I said no

Way Screen!

And grew wings

Tall enough

To forget 
But Screen

Just laughed

At me

And said

You can't

Fly out

Of this

You can't

Even yourself 
- driveway

It stands on target and the pool did that To the ground and the roots aren't there And it spills - I keep taking pictures Of deer eating weeds in the driveway. 


\section{The Computer Tower}

The metal that gathers God installs -

Dispatching me, as though I drove down that weld

Infatuated to believe myself

As keystrokes above the Cathedral's lawn.

Can't you hear its call? Fanblades

Velcroed, tapered valiance felt

Old flying, in its lane, a fence

Chain-linked to its sentience 


\section{Still Electric}

(after B. Dolan)

How often moves

through impulse

I would have

watched the dead leaves

There / should / n't / be / any / more / fog. Should / n't / be / hard / falls

A / rrange / ments / back / pulls. Sim / ple / grunt / pauses. Whis / tle

Pre / vent / ative. Nefarious. / Don't / run. Boy / don’t / boy. List / en

To / logged / talk. / Why / err / where / every / body / does. / I / just

Justiciar! / But, / there / should / n’t / be / any / more / .

There shouldn't be any more fog. Shouldn't be hard falls

Arrangements or back pulls. Simple dumb pauses. Whistle

Preventative. Nefarious. Don't run. Boy don't boy. Listen

To him talk. Wire where everybody's on. I just want. To 
Just watch. Just watch.

How / can / fall / march / re / sickle / pull / ghoul / towel Is / man / my / sent / tin / null? / Air / shown / dents / poles Moo / on / owl / wolf / paws! List / en / boy / move / on.

You / ain't / the / shift / you / a / maze / full / leaf / hacked /

You / ain't / the / shift / you / a / maze / meant / hacked /

Your / first / fake / red / real / is / satiation.

Watch? / The moon. Through? / Itself. / Been trying too.

For over years. / I / Love / when / looker / gives up

Love when look / is / just / look.

Sensational.

The sense that there are is thousands of pieces. I was not

So reattachment happens when lopsided wants it forces

And watches alternative mana grips rests fed / loops

I'm pulling 
rips

pulling

cables

out of

me

ripping

pulls

cables

out

of me

pulp

find

rips

cables

out of

I am

ripped

cables

pulling

out of 


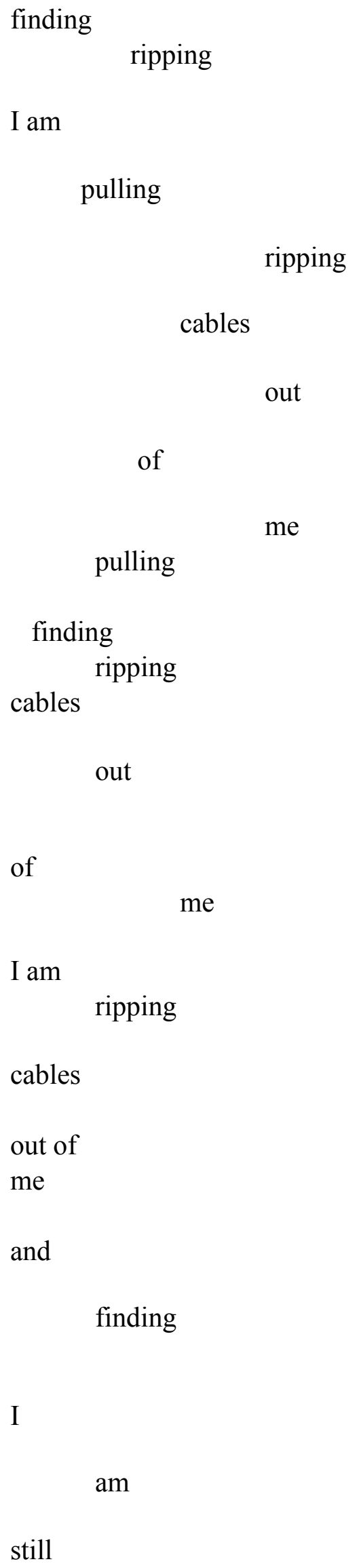


electric 


\section{Companion Song}

Those pixels in the glass you see moving mementos

are Deuz, Orc Warrior (level 70), pre Wrath of the Lich

King, before Cataclysm wrecked streaks through Azeroth

and let us fly over its shattered landscape. Hey Deuz, I said, you belong tanking some Heroic Tempest Keep, or leading the charge in an Arathi Basin, or at least browsing the Auction

House for some underpriced loot. He didn't disagree. Also, I said, I think you're completely lost in this quest for origin and purpose, wide-blind by whatever pretense it is you claim can release you

from that stew portal of static cables you call home. And again he didn't disagree. And when I was in need, I said, you took off down that long distortion, filled with greed, faithless to the very

- at this, Deuz dropped the focus from his hands, turned down a dock I remembered and wept.

I followed him there, sat beside him, and wept. 
- driveway

It stands on target and the swing did that

To my voice and the song doesn't care

But it spills- I keep taking pictures

Of weeds greeting weeds in the driveway. 


\section{Parallax}

last night we slept outside on the lawn

it was beautiful so clear the stars

he tossed and turned having nightmares

this morning he told me he had a vision

about how to finish his script

but now that he's awake it wasn't any good

he said he couldn't go on making the script

because it didn't really express his ideas

last night we slept outside on the lawn

it was beautiful so clear the stars

he tossed and turned having nightmares

this morning he told me he had a vision

about how to finish his script

but now that he's awake it wasn't any good he said it couldn't go on because he didn't

the last night we slept outside on the lawn

it was beautiful so clear the stars 


\section{Circle Drive}

I see a road and a father and a son walking a dog.

I see a road and a father and a son walking.

I see a road and a father and a son.

I see a road and a father.

I see a road. 


\section{Notes:}

- The sections "Warrior Class" and "Arms Specialization" in the poem "You" (page 11) borrows from the WoWWiki (World of Warcraft Wikipedia) website that details the specifications of the Warrior class in the game World of Warcraft (WoW).

- The poem "Scapegoat" (page 20) borrows its title and some language from the rapper Slug in the Atmosphere song titled Scapegoat.

- The poem titled "ALT F4" (page 28) refers to WoW's two button command: $[$ ALT + F4]. When typed in game, WoW abruptly closes and signs the player off.

- $\quad$ Italicized portions in the poems "QUEST TWO" and "QUEST THREE" (pages 36 and 37) are directly taken from two in game WoW quests. They were copied and pasted from the WoWWiki website.

- The first quote on page 41 is from Aimee Mann's song The Moth.

- The second quote on page 41 is from Dante Alighieri's The Divine Comedy (translated by Mark Musa).

- The poem "As A Thing" (page 62) is inspired by Rumi's poem "I Was Dead". 
- The poem "The Computer Tower" (page 67) is inspired by Hart Crane's poem "The Broken Tower".

- The poem "Still Electric" (pages 68 - 72) borrows its title and ending sequence from B. Dolan's spoken word piece Still Electric.

- The poems "Channel For Revival" (pages 59 and 60) and "Companion Song" (page 73) borrow form and some language from Timothy Donnelley's "Passage For Revival" and "To His Own Device", respectively. 